\title{
Malaysian Students' Experience and Motivation using Web-Based Activities to Learn English Language Vocabulary
}

\author{
Noor Zainab binti Abdul Razak, Ameen Akeem, Mohd Khairul Affendy bin Ahmad
}

\begin{abstract}
The place of technology in teaching and learning is established. However, there is the need to consider motivational variables in the use of technology as relating to language learning. This paper thus explored the Malaysian students' experience and motivation using web-based activities in learning English vocabulary. Questionnaire was administered on the selected sample of the pupils and the data were analyzed using simple percentage. Finding revealed that the students had adequate experience using technology and felt motivated using web-based activities in learning vocabulary. These findings show that Malaysian's status in terms of using technology to solve classroom problem. It was this concluded that the use of technology related activities and applications should be encouraged.

Index Terms: Motivation, Vocabulary, Web-Based Activities
\end{abstract}

\section{INTRODUCTION}

The emergence of technology in 21 st century learning environment serves an opportunity for education development. The use of Information and Communication Technology or ICT is widely used throughout the nation. The importance of technology has been realized through globalization, where information can be accessed at our fingertips. This leads to the concept that technology makes learning easier and plays important part in collecting and comprehending information, as well as giving information to others using the Internet as a medium [1].

Teachers are thus expected to always be creative and innovative in their attempts to apply new methods of teaching, including using the technology. In this $21^{\text {st }}$ century learning, technology provides new approach in teaching and learning activities with diverse choices as teaching aids for language learning. However, motivation is an important variable in language learning. According to [2], motivation is a key factor for explaining the success or failure of any difficult activity. It is believed that success in a task is due to the fact that learners are motivated. It is thus easy in second language learning to state that a learner will be successful with the right motivation.

Therefore, considering the invaluable role of technology in education as well as the importance of motivation, this paper

Revised Manuscript Received on September 22, 2019.

Noor Zainab binti Abdul Razak, Language Academy, Universiti Teknologi Malaysia, Skudai, Malaysia.

Ameen Akeem, Faculty of Education, Universiti Teknologi Malaysia, Skudai, Malaysia.

Mohd Khairul Affendy bin Ahmad, Johor Primary School, Johor Bahru, Malaysia. intends:

a. To examine Malaysian pupils' experience using computer and internet; and

b. To investigate Malaysian pupils' motivation towards the use of web-based activities to learn English language vocabulary.

\section{METHODOLOGY}

This study was carried out on the pupils of a primary school in Johor Bahru, Johor. The respondents consisted of 405 th year pupils who were purposively selected based on their English language proficiency level. The pupils chosen were those who obtained Grade $\mathrm{C}$ in the English language subject in their 4th final year examination. This study investigated the pupils' experience using computer and internet; and their motivation towards the use of web-based activities to learn English language vocabulary.

The quantitative research design was engaged in this study. The study collected information through questionnaire. This was to enhance easy understanding of the items. The data from the questionnaire were analyzed manually according to the percentages and frequencies.

\section{LITERATURE REVIEW}

\section{A. Motivation in Language Learning}

Motivation is a key factor for explaining the success or failure of any difficult activity [2]. It has been argued that success in a language task is due to the fact that the language learner is motivated. This has been supported by numerous studies. For instance, [3] said that instrumental motivation plays more important role in EFL learning. This was supported by [4] who declared that motivated learners spend much of their time to gain aims in learning foreign language and motivated learners can also learn language more effectively than unmotivated ones. According to [5], learners with strong desire to learn a language can obtain high level of competence in the target language.

According to Pourhose in Gilakjani, Leong, and Saburi (2012) in [2], the success of any action is dependent on the extent to which persons try to get their goal, along with their desire to do so. Generally, people refer to this psychological factor, the impulse that generates the action, as motivation. It is a motive force 
that arouses, incites, or stimulates action.

Thus, as argued by [2], motivation is an important factor in specifying the readiness of learners to communicate. It refers to the combination of attempt plus desire to obtain the objective of learning the language plus desirable attitudes towards learning the language. By implication, motivation to learn a second language refers to the extent to which the individual works or tries to learn the language because of a desire to do so and the contentment experienced in this task.

\section{B. Computer Assisted Language Learning (CALL) in Malaysia}

According to Chan (2002) in [6], Malaysia had for a long time introduced a variety of initiatives to help the implementation of technology to improve life and learning. Today, there is much use of the computer and Internet in education. This could be due to the decrease in the price of computers and their availability throughout the world. [7] held that technology, particularly CALL, helps the teachers with the educational processes by presenting new possibilities of learning strategies and uses two-way communications between the user and the computer.

[8] stated that the implementation of CALL in schools is increasing, thus efforts need to be accelerated to make certain the improvement of the education system. According to [9], the uses of the computers are now perceptible in education due to its capabilities to be programmed for interactive activities for learning environment.

Computers have been in Malaysian schools since the late 1980s. The use of these learning tools however has not been fully used in the school. According to [10], the country's Ministry of Education agreed that the computers were only used as complement to the normal classroom learning and audio-visual aids. The main information-provider in the language learning is the teachers, who hardly use computers in teaching and learning sessions. The use of computers is minimal in the ordinary teaching and learning session.

\section{Role of Technology in Language Teaching and Learning}

Computer Assisted Language Learning (CALL) was developed to teach the language in learning process through the use of computers. Learning via computers and Internet can contribute to successful language learning [11]. The Internet is a powerful tool for teachers in teaching and for pupils in learning because it opens to the access of abundant collection of learning resources. It includes pictures, sounds, colourful settings, teaching and learning ideas, and promotes interactivity between the computer and pupils.

In addition, in order to increase vocabulary learning, the resources through computer and Internet can be used and adapted to suit the pupils' proficiency level. [12] stated that the Internet is an information highway which serves as a brilliant global network with millions of people and computers connected to one another. Thus, the teachers are responsible to use the powerful teaching tools in teaching and learning session to increase learning abilities among pupils.

Moreover, the increase of information and communication technology of ICT use around the world provides importance for education system to use the technology in teaching and learning. This is due to the rising use of information technology worldwide. [11] suggested that teachers need to be familiar with technology as it is an important skill to teach in today's modern classrooms.

The role of computer and Internet in teaching and learning has thus been stressed in various studies [13]. Primary school pupils learn how to use technology in schools with the basic knowledge in handling the usual gadgets such as computers and netbooks during computer laboratory classes. Therefore, introducing the use of technology as one of the tools to teach vocabulary is a perfect chance for teachers and pupils to expand their knowledge.

\section{RESULTS AND FINDINGS}

The findings of the data collected through the administration of the questionnaire are presented herein.

\section{A. Pupils' Experience in Using Computer and Internet}

Lack of experience of using ICT would result into hindrance to learning vocabulary using web-based activities, and may give inaccurate results. Hence, the study decided to gather and evaluate the respondents' ability to use computer and the Internet. The findings from the information will indicate respondents' capability in using and managing their learning process using the computer. This information will also provide an important insight into the level of technology use among students in Malaysia.

\section{a. Do you own a Personal Computer?}

Table I: Survey Result of Respondents Owning Computers

\begin{tabular}{|c|c|c|}
\hline Statement & Yes & No \\
\hline I have a computer & $40(100 \%)$ & $0(0 \%)$ \\
\hline
\end{tabular}

Table I shows that all the respondents owned a computer at home. This information is important considering the fact that computer has become a necessity when it comes to today's lifestyle. Hence, it is no surprise if all respondents own a computer in each household, where it assists and helps by making searching and gathering information easier. The findings are fitting due to the fact that the pupils of the school mainly come from educated and modern families. From the findings, the researcher also concluded that using computer among the respondents will not be a problem since all of them are familiar with the device.

\section{b. Do you have Basic Knowledge in Handling Computer?}

Table II: Survey Result of Respondents' Knowledge in Handling Computers

\begin{tabular}{|c|c|c|}
\hline Statement & Yes & No \\
\hline I know how to use a computer & $40(100 \%)$ & $0(0 \%)$ \\
\hline
\end{tabular}

Table II showed the forty respondents stating that they know how to use the computer. This implies that all respondents have basic knowledge on handling a computer. This may not be unconnected to the availability of a computer in every household through which the pupils indirectly learn the skills to handle and know the basic in computer. 
c. Where is your Preferred Place in Using Computers?

Table III: Survey Result of Respondents' Preferred Place in using Computers

\begin{tabular}{|c|c|c|}
\hline Place & $\begin{array}{c}\text { Number of } \\
\text { Respondents }\end{array}$ & Percentage (\%) \\
\hline Home & 28 & 70 \\
\hline School & 12 & 30 \\
\hline Library & 0 & 0 \\
\hline Cyber Café & 0 & 0 \\
\hline Other & 0 & 0 \\
\hline
\end{tabular}

Table III shows as much as 70 percent of the respondents who preferred to use computers at home, and the other 30 percent of the respondents who liked to use computer at school. There is no response in the other place stated in the item of the questionnaire. This could be due to comfortability or time constraints in those other places.

\section{d. Do you have Connection to the Internet at Home?}

Table IV: Survey Result of Respondents' who have Connection to the Internet at Home

\begin{tabular}{|c|c|c|}
\hline Statements & Yes & No \\
\hline I have Internet connection at home & $40(100 \%)$ & $0(0 \%)$ \\
\hline
\end{tabular}

Referring to table IV, it showed that 100 percent of the respondents have the Internet connection at home. The finding showed that the existence of Internet connection in every household is important and necessary in today's society. It could be argued that the respondents may use the Internet to surf the web-based activities at home.

\section{e. What is the Average Time Spent Using a Computer per Day?}

Table V: Survey Result of Respondents' Average Time Spent Using the Computer per Day

\begin{tabular}{|c|c|c|}
\hline $\begin{array}{c}\text { Average hours spend using } \\
\text { the computer per day }\end{array}$ & $\begin{array}{c}\text { Number of } \\
\text { Respondent }\end{array}$ & $\begin{array}{c}\text { Percentag } \\
\text { e (\%) }\end{array}$ \\
\hline Less than one hour & 12 & 30 \\
\hline 1-2 hours & 18 & 45 \\
\hline 3-4 hours & 7 & 17.5 \\
\hline More than 3 hours & 3 & 7.5 \\
\hline Total & 40 & 100 \\
\hline
\end{tabular}

Table $\mathrm{V}$ demonstrated that 12 respondents (30 percent) spend less than an hour to use the computer, 18 respondents (45 percent) spend one to two hours on the computer, 7 respondents (17.5 percent) spend three to four hours a day using the computer, and 3 respondents spend more than 3 hours per day to use the computer. This showed that majority of the respondents have a lot of experience in using the computer in their daily life. The time they spend using the computer also indicates that the respondents have less restraints from parents to use the computers.

\section{f. Pupils' Motivation towards using Web-Based Activities to Learn English Language Vocabulary}

Table VI: Questionnaire to Investigate the Respondents' Motivation towards using Web-Based Activities to Learn English Language Vocabulary

\begin{tabular}{|c|c|c|c|}
\hline No & Statements & Yes & No \\
\hline 1 & I feel more interested to learn & $100 \%$ & $0 \%$ \\
\hline
\end{tabular}

\begin{tabular}{|c|c|c|c|}
\hline & $\begin{array}{c}\text { English language vocabulary } \\
\text { when using web-based activities } \\
\text { in English class. }\end{array}$ & & \\
\hline 2 & $\begin{array}{l}\text { I feel motivated to learn English } \\
\text { vocabulary when using } \\
\text { web-based activities in English } \\
\text { class. }\end{array}$ & $100 \%$ & $0 \%$ \\
\hline 3 & $\begin{array}{c}\text { I am looking forward to use the } \\
\text { web-based activities to learn } \\
\text { English vocabulary in the next } \\
\text { class. }\end{array}$ & $100 \%$ & $0 \%$ \\
\hline 4 & $\begin{array}{c}\text { I can do my own English } \\
\text { vocabulary learning using the } \\
\text { web-based activities. }\end{array}$ & $82.5 \%$ & $17.5 \%$ \\
\hline 5 & $\begin{array}{l}\text { I can find more exercise to } \\
\text { practice the vocabulary taught by } \\
\text { the teacher using the web-based } \\
\text { activities. }\end{array}$ & $80 \%$ & $20 \%$ \\
\hline 6 & $\begin{array}{l}\text { I feel confident that I can learn } \\
\text { more English language } \\
\text { vocabulary using the web based } \\
\text { activities. }\end{array}$ & $100 \%$ & $0 \%$ \\
\hline 7 & $\begin{array}{l}\text { I feel positive that I can } \\
\text { understand new English } \\
\text { language vocabulary better when } \\
\text { using the web-based activities. }\end{array}$ & $100 \%$ & $0 \%$ \\
\hline 8 & $\begin{array}{l}\text { I do not want to use the } \\
\text { web-based activities to learn } \\
\text { English vocabulary at all. }\end{array}$ & $0 \%$ & $100 \%$ \\
\hline 9 & $\begin{array}{l}\text { I feel bored when using the } \\
\text { web-based activities to learn } \\
\text { English language vocabulary. }\end{array}$ & $0 \%$ & $100 \%$ \\
\hline 10 & $\begin{array}{l}\text { I feel that I cannot understand the } \\
\text { new English vocabulary better } \\
\text { using the web-based activities. }\end{array}$ & $0 \%$ & $100 \%$ \\
\hline 11 & $\begin{array}{l}\text { I do not think that I can perform } \\
\text { better in the examination when } \\
\text { learning English vocabulary } \\
\text { using web-based activities. }\end{array}$ & $0 \%$ & $100 \%$ \\
\hline 12 & $\begin{array}{c}\text { I do not want to use the } \\
\text { web-based activities to learn } \\
\text { English vocabulary when I am } \\
\text { learning by myself. }\end{array}$ & $0 \%$ & $100 \%$ \\
\hline 13 & $\begin{array}{l}\text { I do not think that I need to use } \\
\text { the web-based activities to learn } \\
\text { English vocabulary. }\end{array}$ & $22.5 \%$ & $77.5 \%$ \\
\hline 14 & $\begin{array}{l}\text { I do not think that I need to use } \\
\text { the web-based activities to make } \\
\text { me feel motivated to learn } \\
\text { English vocabulary. }\end{array}$ & $20 \%$ & $80 \%$ \\
\hline 15 & $\begin{array}{l}\text { I do not think that I need to use } \\
\text { the web-based activities to help } \\
\text { me to learn English vocabulary } \\
\text { better. }\end{array}$ & $15 \%$ & $85 \%$ \\
\hline
\end{tabular}

As seen in table VI, there are fifteen items designed in this questionnaire to investigate the respondents' motivation towards using web-based activities to learn English language vocabulary. The first and the second items of the questionnaire state that the respondent feel more interested and motivated to learn English language vocabulary using web-based activities. All respondents agreed fully 
to the statements. This could be because the web-based activities provide colorful and attractive features and design that can help to attract respondents' interest in learning.

In support of this, the respondents also fully agreed to the third statement of the questionnaire stating that they were looking forward to use web-based activities to learn English language vocabulary in the next class.

Next, 17.5 percent of the respondents do not agree that they can do their own English language vocabulary using web-based activity. This simply implies that the respondents cannot do the activities in the web without the guide of the teachers. However, majority of the respondents agree that they can do their own learning using the web-based activities. The fifth item lends credence to this where 20 percent of the respondents held that they can find more exercise to practice the vocabulary taught by the teacher using the web-based activities while 80 percent of the respondents however said they can do more exercises without the teacher.

For item 6 and item 7, majority of the respondents expressed their confidence and positive feeling about the use of web-based activities to learn English vocabulary. They said they enjoy using computers and Internet during lesson.

The questionnaire items reveal that the majority of the respondents love to use web-based activities to learn English language vocabulary. They also do not feel bored when using the web-based activities while learning. They also can understand new English words easily using web-based activity. Using the web-based activity, the respondents believe they can perform better in the examination when using web-based activities. Using web-based activities is also the preference for the respondents for self- learning. The importance of learning web-based activities to learn English language vocabulary is also recognized among the majority of the respondents. The respondents realized that they can be motivated when using web-based activities, due to the attractiveness of the web. The uses of web-based activities also enhance the respondents' ability to learn English language vocabulary better.

All these responses indicate that the respondents have the positive motivation towards the use of web-based activities in learning English language vocabulary. The use of computer and Internet undeniably put a strong motivation towards learning process. However, there are small portion of pupils that have to be guided when using computers. Hence, for this minority, the computer use must be done in face-to-face manner.

\section{CONCLUSION}

From this study, we can see that the use of web-based activities had increased the respondents' motivation where they felt more interested in learning the vocabulary. It is also believed that learning using web-based activities is interesting and motivating. This finding is supported by the result from the study by Kreutz and Rhodin (2016) who found that majority of students have positive motivations in language learning using the computer and the Internet [14].

\section{REFERENCES}

1. Adam, M. H. \& Nor Zairah, A. (2014). The influence of social networking sites on students' academic performance in Malaysia. International journal of electronic commerce studies vol.5, no.2, pp.247-254.

2. Al-Hazemi, H. (2000). Lexical Attrition of Some Arabic Speakers of English as a Foreign Language: a Study of WordLoss. Internet TESL J [Serial online] Available from: http://itesli.org/Articles/Al-Hazemi-Attrition/

3. Alizadeh, M. (2016). The Impact of Motivation on English Language Learning. International Journal of Research in English Education, 1(1).

4. Allen, M. W. (2016). Michael Allen's guide to e-learning: Building interactive, fun, and effective learning programs for any company. John Wiley \& Sons.

5. Al-Otaibi, G. (2004). Language Learning Strategy Use among Saudi EFL Students and Its Relationship to LanguageProficiency Lever, Gender. and Motivation [PhD Dissertation]. Indiana (PA): Indiana University ofPennsylvania.

6. Batane, T., \&Mafote, S. (2007). The Impact of WebCT On Learning: A Students'perspective. Educatio: 51(5).

7. Dovedan, Z; Seljan, S; Vučković, K. (2002). Multimedia in Foreign Language Learning, MIPRO: Opatija,72-75.

8. Jacobsen, A. D., Eggen, P. \& Kauchak, D. 2009. Method for Teaching: Promoting Student Learning in K-12 Classroom (8th Ed.). USA: Pearson Publication.

9. Maro, N (2014). The Use of Computers in Public and Private Primary Schools in Tanzania: A Digital Divide. International Journal of Computer Applications. 103(15) 14-19.

10. Mohd Khairul Affendy Bin Ahmad (2018). ESL learners' attitude and motivation towards using web-based activities to learn English language vocabulary. Thesis submitted to Universiti Teknologi Malaysia.

11. Moskovsky, C, G., \& Alrabai, F. A. (2009). Intrinsic Motivation in Saudi Learners of English as a Foreign Language. The Open Applied Linguistics Journal, 21-10.

12. Noor Zainab, A. R. (2004). The Internet and Its Benefits in an ESL Classroom. In Mukudan, J. et al (eds). ELT Matters 1., Issues in English Language Learning and teaching: University Technology Malaysia.

13. Yuen, A. H., Law, N., \& Wong, K. C. (2003). ICT implementation and school leadership: Case studies of ICT integration in teaching and learning. Journal of Educational Administration, 41(2), 158-170.

14. Kreutz, J.,Rhodin,N. (2016). The Influence of ICT on Leaners' Motivation towards Learning English. Degree Project in English and Learning (Malmö Högskola Fakulteten för Lärande och Samhälle). Retrieved from: https://muep.mau.se/bitstream/handle/2043/20747/Degree\%20Project\%2 0Josefin $\% 20 \& \% 20$ Natalie.pdf?sequence $=2$.

\section{AUTHORS PROFILE}

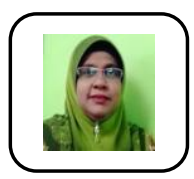

Noor Zainab binti Abdul Razak, is an ESL/Education lecturer at the Language Academy, UTM. Her research interests include the areas of computer assisted language learning, motivational orientations towards learning English language and language learning strategies. She has published papers both nationally and internationally in her field of interest.

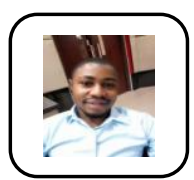

Ameen Akeem, PhD student Teaching English as a Second Language, Universiti Teknologi Malaysia.

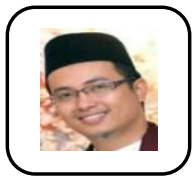

Mohd Khairul Affendy Bin Ahmad, He obtained Med TESL from UTM. At present a school teacher. Teaching at a primary school in Johor. 